\title{
Bentuk Fasade Gereja Protestan di Kota Bandung
}

\author{
${ }^{1}$ Nova Chandra Aditya $\mid{ }^{2}$ Jhon Walter Purba $\mid{ }^{3}$ Salmon Priaji Martana \\ Program Studi Teknik Arsitektur, Universitas Komputer Indonesia, Bandung, Jawa Barat, \\ Indonesia \\ Email: ketuapt@unikom.ac.id
}

\begin{abstract}
ABSTRAK
Gereja merupakan tempat peribadatan umat kristiani, di mana pada awalnya umat Kristen mengadakan pertemuan-pertemuan di rumah ibadah yang dikenal sebagai gereja rumah. Seiring dengan perkembangan zaman pada akhirnya dibuatlah bangunan gereja formal. Gereja tradisional berbeda dengan gereja modern, di mana gereja tradisional cenderung memiliki bentuk menyerupai salib dengan beratapkan kubah dan adanya menara, sementra itu seiring berkembangnya ilmu arsitektur, bentuk gereja menjadi lebih beragam di era modern sesuai dengan jamannya. Hal ini membangkitkan ciri gereja melalui corak fisiknya, yang senantiasa menjadi ciri penampilannya sesuai dengan masa perkembangannya. Gereja dibuat oleh masyarakat Kristiani Indonesia melalui karyanya di dalam melaksanakan ajaran Kristus. Dari observasi sumber primer dan sekunder, di Kota Bandung terdapat enam gereja yang memiliki bentuk beraneka ragam sesuai dengan lokasi gereja tersebut. Meskipun gereja merupakan tempat beribadah secara umum, tidak dipungkiri setiap gereja memiliki ciri khas. Ada gereja yang memiliki fasade modern, ada pula yang memiliki fasade yang mengacu pada adat istiadat penganutnya. Melalui metode survai arsitektural, penelitian ini berusaha menunjukkan wujud dan variasi dari fasade tersebut sesuai dengan latar belakangnya. Pada akhirnya, ditemukan bahwa selain aspek dogmatis, faktor alam lingkungan, iklim, kenyamanan dan beberapa faktor lain juga berperan dalam keputusan desain para perancang mewujudkan karya fasade gereja di Bandung.
\end{abstract}

Kata Kunci: gereja, fasade, Bandung.

\begin{abstract}
The church is a place of worship for Christians, where Christians initially held meetings in houses of worship known as house churches. In line with the times, formal church buildings have been made. The traditional church is different from the modern church, where the traditional church tends to have a cross-shaped shape with a roofed dome and a tower, while that as the development of architecture, the form of the church becomes more diverse in the modern era in accordance with its era. This awakens the character of the church through its physical features, which always characterize its appearance according to its development period. The church was created by the Indonesian Christian community through its work in carrying out the teachings of Christ. From primary and secondary source observations, in the city of Bandung there are six churches that have diverse forms according to the location of the church. Although the church is a place of worship in general, no doubt every church has its own characteristics. Some churches have modern facades, others have facades that refer to the customs of their adherents. Through the architectural survey method, this research tries to show the appearance and variation of the facade according to its background. In the end, it was found that in addition to dogmatic aspects, natural factors of the environment, climate, comfort and several other factors also played a role in the design decisions of the designers to realize the facade of the church in Bandung.
\end{abstract}

Keywords : church, facade, Bandung. 


\section{PENDAHULUAN}

Dua kebutuhan terkait dengan keberadaan manusia secara umum. Pertama adalah kebutuhan jasmani yang terkait dengan performa fisik manusia, yang kedua adalah kebutuhan rohani yang mendasari semua aspek spiritual dan psikis dari keberadaannya (Linton, 1984).

Kebutuhan rohani dalam hidup dapat dipenuhi dengan salah satunya mengikuti kegiatan gerejawi maupun pembangunan rohani. Untuk melakukan kegiatan itu dibutuhkan suatu tempat yang memfasilitasi dan mewadahi aktivitas di dalamnya.

Gereja bukan hanya memiliki tingkat ruang yang fungsional baik secara fisik maupun psikis, sebuah gereja juga memperhatikan bentuk fasade gedung yang seuai dengan kegiatannya. Berbagai jenis bentuk fasade bangunan gereja merupakan pemaknaan yang berbeda-beda yang memiliki satu tujuan. Besar kecilnya pemaknaan dan penghayatan tersebut tergentung dari berbagai faktor, salah satunya faktor lingkungan. Sebuah lingkungan dapat menjadi elemen yang terpenting dalam mendukung pemaknaan dan penghayatan ritual keagamaan yang dilakukan.

Kristen Protestan memiliki pendasaran filosofi teologis yang cukup mendalam sehingga sudah seharusnya dapat terlihat secara langsung pada bangunan gereja. Hal ini merupakan suatu hal yang dapat meningkatkan persepsi relijius umat yang hadir di dalamnya. Namun hal ini hanya bersifat abstrak dan tidak dapat diukur secara pasti pada masing-masing orang.

Dengan demikian sesuai dengan tujuan penelitian diharapkan dapat diketahui pemetaan bentuk fasade gereja Protestan di Bandung termasuk persepsi pengguna gereja itu sendiri, serta mengetahui sejarah fasade gereja Protestan di Bandung pada tahun 1980-2020.

Dari pengamatan tersebut nantinya juga dapat diketahui hal yang mendasari bentuk fasade gereja Protestan di Kota Bandung, melalui perbandingan antara gereja yang satu dengan gereja lainnya.

\section{METODE PENELITIAN}

Survei arsitektural (Unaradjan, 2000) memegang peranan penting di dalam penelitian ini. Enam buah gereja yang dianggap paling representatif mewakili gaya, langgam tertentu beserta dengan masa-masa tertentu dalam pembangunannya dipilih untuk diamati. Elemen-elemen fasade mulai dari atap, jendela, gerbang dan pintu serta pagar diamati dan diperbandingkan. Selain memperbandingkan antar gereja juga dilakukan perbandingan dengan teori-teori seperti teori fasade dari Krier (1988) dan teori bentuk dari Ching (2000) sebagai pisau analisisnya. Data yang dikumpulkan ditabelkan untuk kemudian dijajarkan agar dapat diamati langsung secara visual karakternya dan disimpulkan pertautan, persamaan dan perbedaannya.

\section{PEMBAHASAN}

Kata fasade (façade) berasal dari bahasa latin facies yang merupakan sinonim dari face (wajah) dan appearance (penampilan). Karena itu, berbicara mengenai perwajahan bangunan mesti berkaitan dengan sisi bangunan yang menghadap ke jalan (Krier, 1988).

Fasade bukanlah sesuatu yang memenuhi persyaratan alami yang ditentukan dari organisasi dan ruang di baliknya. Sebuah fasade menyampaikan keadaan budaya saat bangunan itu didirikan, mengungkap kriteria tatanan dan penataan serta memberi kemungkinan dan kreatifitas dalam ornamentasi dan dekorasi.

Bentuk arsitektural adalah titik temu antara massa dan ruang. Dalam hal ini pembentukan sebuah gedung dapat melibatkan penyatuan nsur-unsur bentuk arsitektural, tekstur, material, pemisah antara cahaya dan bayangan serta warna (Ching, 1996).

Fasade adalah representasi atau ekspresi dari berbagai aspek yang muncul yang dapat diamati secara visual. Dalam konteks arsitektur, fasade bangunan tidak hanya bersifat dua dimensi saja akan tetapi juga besifat tiga dimensi yang dapat merepresentasikan masing-masing bangunan tersebut. Umumnya pengamatan pada komponen fasade bangunan mencakup:

- Pagar Pembatas

- Gerbang dan Pintu Masuk (Entrance)

- Zona Lantai Dasar 
- Jendela dan Pintu Masuk Ke Bangunan

- Atap

- Sign dan Ornamen Pada Fasade

\section{Sejarah Gereja.}

Gereja merupakan sebuah rumah ibadah umat Kristen di mana umat berdoa dan bersembahyang. Gedung gereja atau kerap disebut Bait Suci sebagai tempat beribadah pertama kali dibangun oleh Raja Salomo dari Israel pada jaman Perjanjian Lama (I Raja-Raja 6). Sebelumnya untuk beribadah umat Kristen pergi ke tempat kemah pertemuan, bangunan untuk beribadah yang dibangun dari tenda yang dikelilingi dengan tonggak-tonggak kayu. Namun seiring dengan perkembangannya, akhirnya gereja dibangun dalam bentuk gedung. Dari masa ke masa perkembangan gereja semakin besar seiring dengan meluasnya Agama Kristen. Bentuk bangunan gereja juga terpengaruh dengan perkembangan arsitektur pada saat itu, mulai dari masa Romanesque, Gothic, Renaissance, Baroque, Rococo hingga Modern.

Gedung gereja adalah bangunan yang memiliki tujuan memfasilitasi pertemuan sebuah gereja. Bangunan gereja tradisional seringkali berbentuk salib dan memiliki sebuah menara dan beratap kubah. Sedangkan bangunan gereja modern memiliki berbagai variasi dan tata letak secara arsitektur, banyak bangunan yang sebelumnya dirancang untuk tujuan lain kini telah dikonversi untuk digunakan sebaga gereja demikian juga bangunan gereja yang asli yang digunakan untuk fungsi lain.

\section{Arsitektur Gereja.}

Arsitektur gereja merupakan seni pertukangan dari bangunan gereja, di mana fungsi yang menjadi pertimbangan utama dan tujuan dibangunnya gedung gereja adalah murni wadah ibadah. Arsitektur gereja merupakan cerminan dari tata nilai adiluhung ajaran Yesus Kristus, wujud dari sejarah hidup kristianitas, di mana nilai-nilai di dalamnya juga harus memiliki kesatuan dengan ajaranNya.

Masa kebangkitan arsitektur gereja terjadi setelah era 600an Masehi, saat Constantinus dan Karel Agung memberi perubahan signifikan pada keberjalanan sejarah Eropa, sebelum kebangkitan ekonomi dan perkembangan biara di abad ke 11 .

Sebelumnya di tahun 313, Kaisar Constantinus mengumumkan Deklarasi Milan yang berisi pengakuan terhadap ajaran Kristen dan peresmiannya sebagai agama negara (Wright, 2020). Sejak saat itu pembangunan gedung peribadatan Kristen secara formal mulai dilaksanakan dengan desain khusus yang tidak hanya sekadar modifikasi dari fungsi yang sudah ada sebelumnya. Melalui perkembangan yang panjang, gereja secara fisik bertransformasi dari gedung peribadatan biasa menjadi Rumah Tuhan di atas bumi (domus dei) seperti tertulis dalam Guidelines of the National Conference of Catholic Bishops (2000).

Adapun perkembangan bangunan gereja sesuai dengan langgam arsitektur yang berpengaruh signifikan dapat disebutkan sebagai berikut:

\section{Langgam gereja basilika}

Basilika merupakan wadah kegiatan umum di masa kejayaan Romawi. Aktivitas di dalamnya beraneka ragam meliputi pengadilan, perdagangan, dengan tata ruangan fleksibel yang dalam perkembangannya dikemudian hari digunakan oleh gereja. Kata basilika berasal dari bahasa latin berpengaruh Yunani Basiliké Stoà, yang berarti Stoa Kerajaan. Awalnya basilika adalah sebuah bangunan publik Romawi berupa tempat pertemuan yang biasanya terletak di forum -pusat kota. Sebelumnya di kota-kota Yunani kuno, basilika muncul pada abad ke-2 sebelum masehi. Setelah Kekaisaran Romawi resmi mengakui Kristen sebagai agama yang sah, kata basilika berkembang untuk merujuk pada sebuah gereja besar yang peresmiannya diupacarai khusus oleh Paus sendiri. Mulai saat itu, basilika berkembang dengan dua pengertian; satu di sisi arsitektur dan satu lagi di sisi kegerejaan. Bangunan bergaya basilika bisa disaksikan pada Gambar 1 . 


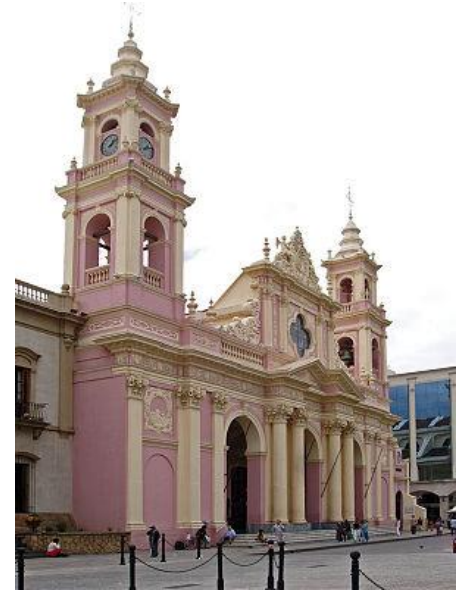

Gbr 1. Bangunan model Basilika.

Sumber : https://id.wikipedia.org/wiki/Basilika

\section{Langgam gereja romanesque}

Romanasque adalah arsitektur yang berkembang pada tahun 1050-1200. Gerejagereja ini memiliki keunikan, yaitu bentuk bangunannya menyerupai puri atau kastil khas Eropa.

Adalah Charles-Alexis-Adrien de Gerville yang untuk pertama kalinya di tahun 1918 mendeskripsikan suatu era yang mencoba untuk kembali menerapkan kejayaan Romawi setelah ratusan tahun masa kelam. Disebut sebagai Romanesque, era ini disebut sebagai Roman di Perancis, Romanish di Jerman dan Romanico di Italia.. Gaya ini berkembang di Eropa mulai tahun 1000an Masehi hingga tahun 1200an. Gaya ini kemudian berganti ke gaya Gothic pada periode setelahnya. Layaknya penyebutannya, gaya arsitektur Romaneque menerapkan banyak elemen Romawi, namun dengan reduksi akibat keterbatasan sumber daya. Berbanding terbalik dengan arsitektur Romawi, arsitektur Romanesque bukanlah arsitektur masyarakat kaya atau penguasa sehingga fasadenya tidak gegap gempita seperti pada periode setelahnya. Ornamennya minim namun bentuknya sudah cukup menggambarkan kebesaran Pencipta.

Saat ini bentuk gereja Romanasque lebih dikenal sebagai gereja dengan menara tinggi, beratap batu dengan ruang besar yang mampu menampung 1000 orang. Tampak atas bangunan berbentuk salib bersayap. Gaya Romanasque lebih menekankan aspek teologis dibanding aspek eksterior. Tampilannya dapat disimak pada Gambar 2.

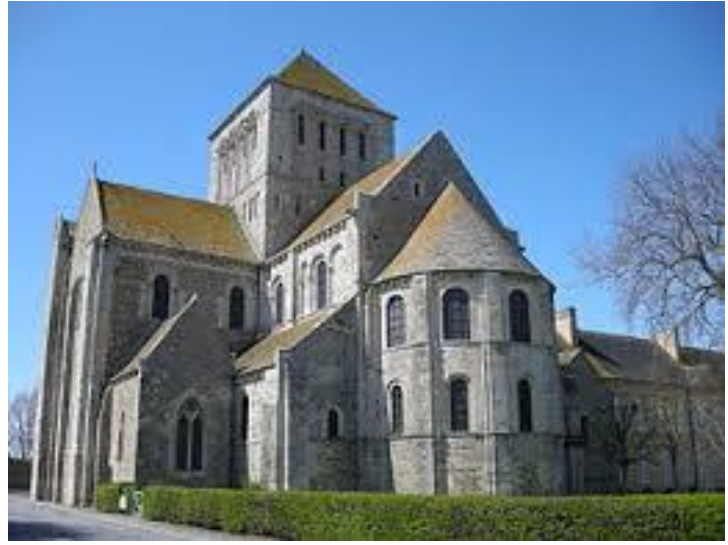

Gbr 2. Bangunan model Romanesque. Sumber:

https://www.britannica.com/art/Romanesquearchitecture

\section{Langgam gereja gothic}

Arsitektur Gothic mulai berkembang di Perancis sekitar abad 13-16. Ciri-cirinya adalah permainan cahaya yang riang gembira, berbanding terbalik dengan Romanesque yang temaram, seperti terlihat pada Gambar 3.

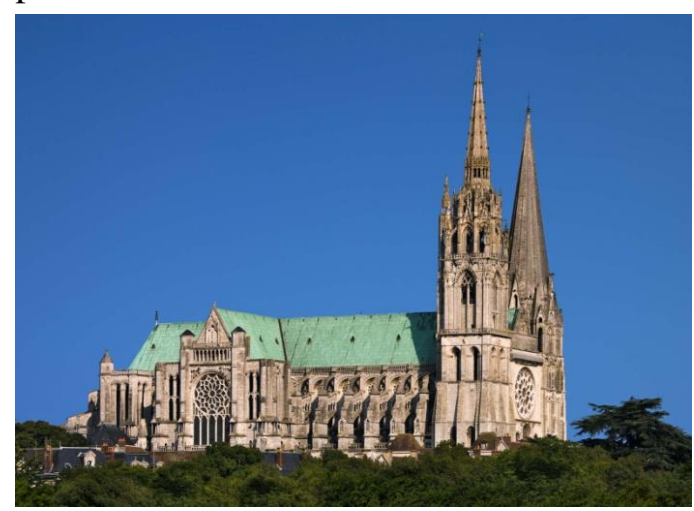

Gbr 3. Bangunan model Gothic.

Sumber : https://www.britannica.com/art/Gothicarchitecture.

Gereja Gotik menjadi rujukan penting dalam arsitektur gereja secara umum, karena pada masa itu gereja mencapai puncak kejayaannya di Eropa, baik dalam kelembagaan, pengaruh sosial -ekonomi, bahkan arsitektur (Martana, 2000). Langgam Gotik merupakan kelanjutan dari Romanesk, saat masa-masa yang suram digantikan oleh kemapanan dan kesejahteraan. Arsitektur Gotik merupakan potret masyarakat Eropa, 
menggambarkan riang-rianya kehidupan dalam ketaatan total pada hegemoni Gereja.

\section{Langgam Katedral.}

Arsitektur katedral merupakan bagian integral dari Arsitektur adiluhung Gotik nan megah. Asal usul Kata katedral dari bahasa latin cathedral yang bermakna tahta uskup. Berkembang di Perancis bagian utara, bangunan didirikan gigantik dengan menara, asupan cahaya dari kaca patri, jendela mawar dan disangga flying butress seperti terlihat pada Gambar 4.

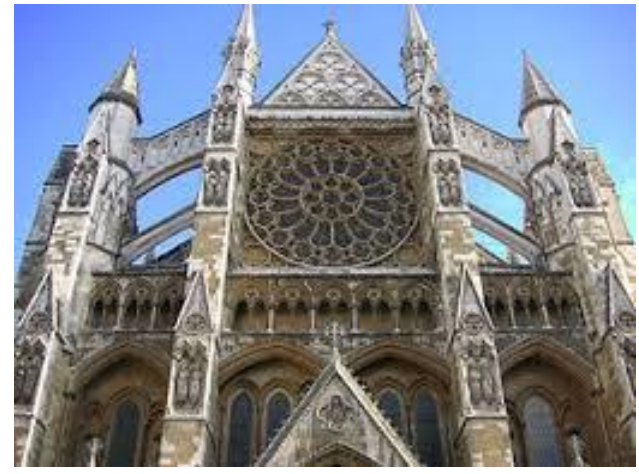

Gbr 4. Arsitektur Katedral.

Sumber :

https://id.wikipedia.org/wiki/Arsitektur_Gereja

\section{Langgam gereja neo gothic.}

Arsitektur neo gothic lahir setelah jaman Renaissanse, Baroque dan Rocco. Neo Gothic dan Gothic adalah kesederhanaan dekorasi bangunan, hal ini dapat dilihat dengan tidak adanya ukiran dan patung yang rumit. Neo Gothic masih menggunakan namun lebih sederhana. Gambarannya bisa dilihat pada Gambar 5.

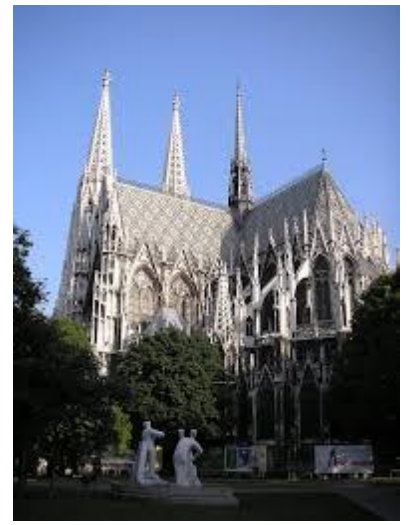

Gbr 5. Bangunan model Neo Gothic. Sumber :

https://id.wikipedia.org/wiki/Arsitektur_Gereja

\section{Modern}

Sebagaimana arsitektur modern, arsitektur gereja modern (Hogg, 2010) berlandas pada aspek kegunaan (utility), kesederhanaan (simplicity), keluwesan (flexibility), kedekatan (intimacy) dan keindahan (beauty). Terlihat seperti pada Gambar 6.

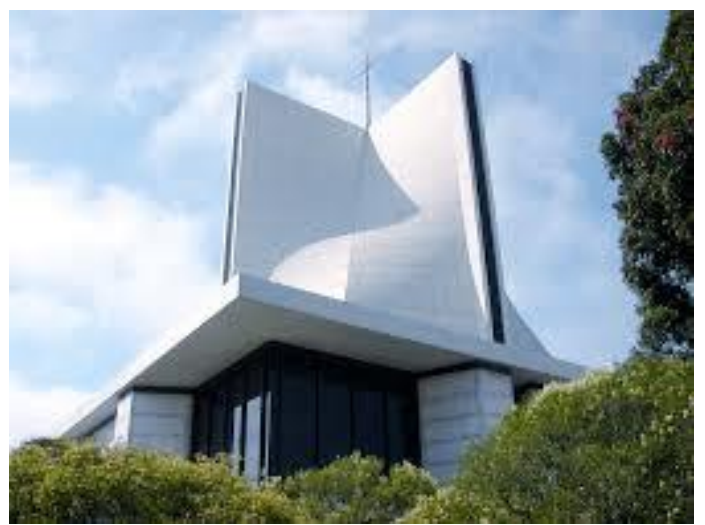

Gbr 6. Bangunan gereja modern. Sumber:

https://www.architectsjournal.co.uk/home/top10-worlds-most-spectacular-modernchurches/8624038.article

Bentuk Fasade Gereja Protestan di Bandung Gereja-gereja Protestan di Bandung sesungguhnya termasuk cukup baru dibandingkan dengan gereja Katolik atau secara umum gereja-gereja di kota-kota utama lainnya di Indonesia. Oleh sebab itu tidak mengherankan bila beragam pengaruh mengenai bentuk dan tatanan dari gerejagereja tersebut, tidak terkecuali perwajahannya.

Pada paruh kedua dekade awal abad 20, tepatnya pada tanggal 1 April 1906, Bandung memperoleh status Gemeente, sehingga mampu menyelenggarakan pengelolaan kota mandiri. Dari saat itu, Kota Bandung mulai bergerak membangun permukiman warga Eropa di bagian utara kota, termasuk di dalamnya kawasan pusat pemerintahan kotamadya dengan Gedung Balaikota yang dilengkapi taman indah menempati lokasi bekas gudang kopi. Menyusul setelah itu didirikan pula bangunan public penunjang aktivitas di sekitarnya meliputi sekolah, gedung perbankan, pos polisi, juga gereja.

Pembangunan gereja Protestan yang pertama di Bandung diawali dengan Gereja Betel di Jalan Wastukancana pada 1 Mei 
1924. Lonceng yang terdapat di menara gereja tersebut permata kali berdentang saat gereja ini diresmikan pada 1 Maret 1925. Gereja ini dirancang oleh arsitek Charles Prosper Wolff Scoemaker bergaya romanesk dengan imbuhan art deco dan ornamentasi lokal.

Menarik bahwa gereja Protestan pertama ini memulai tonggak sejarah gereja Protestan di Bandung dengan semarak pengaruhpengaruh yang terinkulturasi di dalam artifak gereja dan aktivitas umat. Segera setelah itu, gereja-gereja lain bermunculan, seperti Gereja Maranatha di Citarum rancangan Brinkman yang memasukkan pengaruh-pengaruh lokal. Pada perkembangan selanjutnya menuju era modern, muncul gereja yang spesifik mengakomodasi kebutuhan ibadah dari suku-suku tertentu di Indonesia, seperti gereja untuk orang Batak, Manado, Ambon bahkan Cina. Berikut merupakan hasil pengamatan gereja di Bandung.

Tabel 1 menyuarakan banyak hal mengenai bentuk-bentuk fasade pada gereja-gereja yang memiliki pengaruh signifikan dalam kehidupan kristianitas di Bandung. Faktor lingkungan iklim, kenyamanan dan fakor lainnya dapat mempengaruhi bentuk fasade. Lebih khusus terkait ornamen-ornamen spesifik dapat terlihat sebagai berikut.

\section{a. Pagar Pembatas}

Setiap gereja menggunakan pagar pembatas dengan desain yang dipengaruhi dari bentuk gerbangnya sendiri. Pada umumnya gereja yang terletak di pinggir jalan raya didesain sedemikian rupa menggunakan material yang baik, berbeda dengan gereja yang jauh dari jalan raya utama. Sangat nampak pengaruh pragmatism modern-fungsional pada pembatas lokasi gereja-gereja di Bandung, karena pada desain asal gereja-gereja Eropa elemen ini dapat dinafikan.

\section{b. Gerbang}

Bentuk gerbang dipengaruhi oleh berbagai hal seperti lokasi yang tidak memungkinkan untuk memberikan ruang parkir bagi kendaraan bermotor pada area gedung. Hal seperti ini akan memberikan ukuran gerbang masuk yang relatif kecil. Faktor keramaian dan lokasi gedung juga dapat mempengaruhi desain sebuah gerbang, sehingga membuat gereja yang dominan terdapat di pinggir jalan raya pasti mempunyai fasade yang lebih menarik dari cantiknya penataan elemen gerbang.

\section{c. Jendela dan Pintu Masuk Bangunan}

Penggunaan jendela pada gedung gereja sangat minim, mirip pada bangunan Romanesque sehingga dalam konteks tropis tidak sesuai dengan fungsi utama jendela sebagai ventilasi ruangan. Tetapi, dari sisi kekusyukan beribadah, minimnya sinar yang masuk menimbulkan efek temaram yang kontemplatif di bagian interior. Pintu masuk bangunan relatif sama di setiap gereja, karena lebih efisien dan seimbang dengan fasilitas yang terdapat di dalamnnya.

\section{Atap}

Gereja hampir seluruhnya memiliki atap yang sama yaitu atap datar dan atap miring, dari bentukan atap itu dapat disimpulkan jika bangunan yang memiliki atap datar di desain dengan baik untuk memberikan ruang di atas gedung sebagai taman atau tempat lainnya. Sedangkan gedung gereja yang beratap miring relatif lebih mudah perawatannya karena sesuai dengan iklim curah hujan di Kota Bandung.

\section{Ornamen}

Hampir seluruh gereja Protestan tidak menggunakan ornamen pada fasade, jikapun ada hanya sebagian kecil yang dipengaruhi bentuk-bentuk era art noveau.

\section{Menara}

Penggunaan menara pada gereja-gereja di Bandung masih berbanding seimbang dengan gereja yang tidak menggunakan menara. Pernah ada suatu masa di mana menara pada bangunan sudut menjadi tren arsitektur di Kota Bandung, di mana bahkan rumah pribadi pun menggunakannya. Gereja-gereja yang dibangun di era tersebut mungkin tidak benar-benar hendak mewujudkan menara dengan fungsi dan pemahaman yang sama dengan gereja bermenara di masa Romanesque dan Gothic. 
Tabel 1. Analisis Fasade Gereja-gereja Protestan di Kota Bandung

Sumber : Aditya, 2020

\begin{tabular}{|c|c|c|c|c|c|c|c|c|}
\hline \multirow[b]{2}{*}{ No } & \multirow[b]{2}{*}{ Gereja } & \multicolumn{7}{|c|}{ ANALISIS FASADE } \\
\hline & & $\begin{array}{l}\text { Aliran } \\
\text { Protestan }\end{array}$ & Atap & Jendela & Pintu Masuk & Gerbang & Lokasi Gedung & $\begin{array}{c}\text { Tahun } \\
\text { dibangun/dir } \\
\text { enovasi }\end{array}$ \\
\hline 1 & $\begin{array}{l}\text { GEREJA KRISTEN } \\
\text { IMANUEL }\end{array}$ & 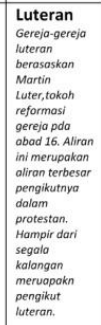 & Menggunakan atap miring & $\begin{array}{l}\text { Tidak enggunakan } \\
\text { jendela }\end{array}$ & $\begin{array}{l}\text { - Pintu jensis swing, } \\
\text { - Pintu masuk } \\
\text { berukuran besar } \\
\text { - Menggunakan } 2 \\
\text { bukaan }\end{array}$ & $\begin{array}{c}\text { Gerbang } \\
\text { didesain dengan } \\
\text { baik dan cukup } \\
\text { tinggi }\end{array}$ & $\begin{array}{l}\text { URBAN } \\
\text { Berada } \\
\text { disekitar } \\
\text { jalan raya }\end{array}$ & $\begin{array}{c}\text { Direnovasi } \\
\text { pada tahun } \\
1990\end{array}$ \\
\hline 2 & $\begin{array}{l}\text { GEREJA KRISTEN } \\
\text { PROTESTAN } \\
\text { SIMALUNGUN }\end{array}$ & 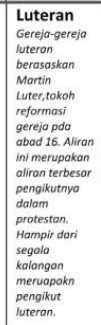 & Menggunakan atap miring & $\begin{array}{l}\text { Menggunakan } \\
\text { jendela }\end{array}$ & $\begin{array}{l}\text { - Pintu jensis swing, } \\
\text { - Pintu masuk } \\
\text { berukuran besar } \\
\text { - Menggunakan } 2 \\
\text { bukaan }\end{array}$ & $\begin{array}{l}\text { Gerbang } \\
\text { didesain } \\
\text { sederhana dan } \\
\text { cukup rendah }\end{array}$ & $\begin{array}{l}\text { URBAN } \\
\text { Berada } \\
\text { jauh dari } \\
\text { jalan raya }\end{array}$ & $\begin{array}{c}\text { Dibangun } \\
\text { pada tahun } \\
1986\end{array}$ \\
\hline 3 & $\begin{array}{l}\text { GEREJA KRISTEN } \\
\text { PROTESTAN } \\
\text { INDONESIA } \\
\text { CILIWUNG }\end{array}$ & 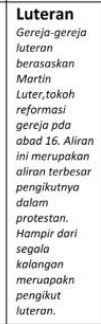 & Menggunakan atap miring & $\begin{array}{l}\begin{array}{c}\text { Menggunakan } \\
\text { jendela }\end{array} \\
\text { and }\end{array}$ & $\begin{array}{l}\text { - Pintu jensis swing, } \\
\text { - Pintu masuk } \\
\text { berukuran besar } \\
\text { - Menggunakan } 2 \\
\text { bukaan }\end{array}$ & $\begin{array}{c}\text { Gerbang } \\
\text { didesain dengan } \\
\text { baik dan cukup } \\
\text { tinggi }\end{array}$ & $\begin{array}{l}\text { URBAN } \\
\text { Berada } \\
\text { disekitar } \\
\text { jalan raya }\end{array}$ & $\begin{array}{l}\text { Direnovasi } \\
\text { tahun } 2011\end{array}$ \\
\hline 4 & GBI SUKAWARNA & $\begin{array}{l}\text { Karismatik } \\
\text { Merupakan } \\
\text { aliran yong } \\
\text { baru dari } \\
\text { protestan } \\
\text { yang } \\
\text { mengutamaka } \\
\text { nucapan } \\
\text { trimakasih } \\
\text { atos kosih } \\
\text { karunia dalam } \\
\text { setiap } \\
\text { kebaktian. } \\
\text { Unumnya } \\
\text { pengikut } \\
\text { aliran ini } \\
\text { adalah } \\
\text { pengusaha. }\end{array}$ & Menggunakan atap datar & $\begin{array}{c}\text { Tidak } \\
\text { menggunakan } \\
\text { jendela }\end{array}$ & $\begin{array}{l}\text { - Pintu jensis swing, } \\
\text { - Pintu masuk } \\
\text { berukuran besar } \\
\text { Menggunakan } 2 \\
\text { bukaan }\end{array}$ & $\begin{array}{c}\text { Gerbang } \\
\text { didesain dengan } \\
\text { baik dan cukup } \\
\text { tinggi }\end{array}$ & $\begin{array}{l}\begin{array}{l}\text { URBAN } \\
\text { Berada } \\
\text { disekitar } \\
\text { jalan raya }\end{array} \\
\text { JI.Aruna No.19, } \\
\text { Bandung }\end{array}$ & $\begin{array}{l}\text { Di bangun } \\
\text { tahun } 2010\end{array}$ \\
\hline 5 & $\begin{array}{l}\text { GEREJA } \\
\text { GERAKAN } \\
\text { PENTAKOSTA } \\
\text { SHALOM }\end{array}$ & $\begin{array}{l}\text { Pentakosta } \\
\text { Adalah } \\
\text { gerokan } \\
\text { dolam } \\
\text { protestan } \\
\text { yang } \\
\text { menekankan } \\
\text { peronan- } \\
\text { peranan } \\
\text { karunia roh } \\
\text { kudus. Aliran } \\
\text { inis sangot } \\
\text { mirip dengan } \\
\text { karismatik. } \\
\text { Pengikut } \\
\text { aliran ini } \\
\text { pengusaha } \\
\text { don } \\
\text { masyorakat } \\
\text { biasa pada } \\
\text { umumny. }\end{array}$ & $1+\frac{1}{3}$ & $\begin{array}{l}\text { Menggunakan } \\
\text { jendela }\end{array}$ & $\begin{array}{l}\text { - Pintu jensis swing, } \\
\text { Pintu masuk } \\
\text { berukuran besar } \\
\text { - Menggunakan } 2 \\
\text { bukaan }\end{array}$ & $\begin{array}{c}\text { Gerbang } \\
\text { didesain } \\
\text { sederhana dan } \\
\text { cukup rendah } \\
\end{array}$ & $\begin{array}{l}\text { URBAN } \\
\text { Berada } \\
\text { disekitar } \\
\text { jalan raya }\end{array}$ & $\begin{array}{l}\text { Dibangun } \\
\text { tahun } 1992\end{array}$ \\
\hline 6 & $\begin{array}{c}\text { GEREJA HKBP } \\
\text { BANDUNG BARAT }\end{array}$ & $\begin{array}{l}\text { Luteran } \\
\text { Gereja-gereja } \\
\text { luteran } \\
\text { berasaskan } \\
\text { Martin } \\
\text { Luter, tokoh } \\
\text { reformasi } \\
\text { gereja pda } \\
\text { abad 16. } \\
\text { Aliran ini } \\
\text { merupakan } \\
\text { aliran terbesar } \\
\text { pengikutnyo } \\
\text { dalam } \\
\text { protestan. } \\
\text { Hampir dori } \\
\text { segala } \\
\text { kalangan } \\
\text { meruopokn } \\
\text { pengikut } \\
\text { luteran. }\end{array}$ & Menggunakan atap miring & $\begin{array}{c}\text { Menggunakan } \\
\text { jendela }\end{array}$ & $\begin{array}{l}\text { - Pintu jensis swing, } \\
\text { - Pintu masuk } \\
\text { berukuran besar } \\
\text { Menggunakan } 2 \\
\text { bukaan }\end{array}$ & $\begin{array}{l}\text { Gerbang } \\
\text { seadanya }\end{array}$ & $\begin{array}{l}\text { URBAN } \\
\text { Berada } \\
\text { jauh dari } \\
\text { jalan raya }\end{array}$ & $\begin{array}{c}\text { Dibangun } \\
\text { pada tahun } \\
1997\end{array}$ \\
\hline
\end{tabular}




\section{SIMPULAN}

Penataan fasade pada bangunan-bangunan gereja Protestan di Kota Bandung diawali dengan semangat keberagaman penerapan berbagai langgam arsitektural termasuk di dalamnya langgam-langgam lokal. Seiring dengan perkembangan zaman, pragmatism rancangan banyak mengambil peran. Batasan kekuatan finansial, efisiensi serta rasionalitas banyak berpengaruh dalam bentukan fasade gereja sebagai sarana dialog antara perancang dengan pengguna bangunan sehingga pada akhirnya dengan juga adanya elemen-elemen eklektik dari gereja suku mengakibatkan fasade gereja Protestan di Bandung tumbuh menjadi cukup variatif namun tetap menjaga kesederhanaannya, sesuai dengan semangat Protestan yang digulirkan mula-mula.

\section{REFERENSI}

[1] Ching, F.D.K. (2000). Arsitektur Bentuk, Bentuk, Ruang dan Tatanan. Jakarta: Erlangga.

[2] Editors of Encyclopaedia Britannica. (2020a) Romanesque Architecture. In Encyclopaedia

Britannica. Retrieved from URL https://www.britannica.com/art/Roman esque-architecture

[3] Editors of Encyclopaedia Britannica. (2020b) Gothic Architecture. In Encyclopaedia Britaniica. Retrieved from URL https://www.britannica.com/art/Gothicarchitecture

[4] Hogg, S. (2020). Top 10: World's most spectacular modern churches. Retrieved from URL https://www.architectsjournal.co.uk/home/t op-10-worlds-most-spectacular-modernchurches/8624038.article

[5] Krier, R. (1996). Komposisi Arsitektur.Surabaya: Erlangga.

[6] Linton, R. (1984) : The study of man. Bandung: Jemmars.

[7] Martana, S.P. (2010). Pola Inkulturasi Gereja-Gereja Katolik dan Protestan di Bali dan Jawa Tengah. Disertasi: Program Doktor Arsitektur, Institut Teknologi Bandung.
[8] Unaradjan, D. (2000). Pengantar Metode Penelitian Ilmu Sosial. Jakarta: Grasindo.

[9] U.S. Catholic Bishops - Committee on the Liturgy. (2000). Built of Living Stones:Art, Architecture, and Worship, Guidelines of the National Conference of Catholic Bishops. New York: United States Conference of Catholic Bishops.

[10] Wikipedia. (2020) Basilika. In Wikipedia. Retrieved from URL https://en.wikipedia.org/wiki/Basilika

[11] Wright, D.F. (2020). 313 The Edict of Milan. Retrieved from URL https://www.christianitytoday.com/hist ory/issues/issue-28/313-edict-of$\underline{\text { milan.html }}$ 